\title{
EL DERECHO COMÚN PRESUPUESTO EN EL ORDENAMIENTO JURÍDICO NACIONAL. UNA REVISIÓN DE SU CONTENIDO
}

\author{
IUS COMMUNE AS A FOUNDATION OF THE NATIONAL LEGAL \\ SYSTEM. A REVIEW OF ITS CONTENT
}

\section{Claudia Carolina Mejías Alonzo*}

\begin{abstract}
RESUMEN: A partir de la constatación de que nuestro ordenamiento jurídico presupone una categoría, el derecho común, el objetivo de este trabajo es precisar su contenido actual. Tras revisar y descartar su identificación con el Código Civil, los principios generales del derecho y la Constitución Política de la República, proponemos, como interpretación posible, vincularlo con la dogmática jurídica, con el acervo común construido y desarrollado por esta, a lo largo de la historia de la institución de que se trate.
\end{abstract}

Palabras clave: Derecho común, derecho civil, principios generales del derecho, Constitución, dogmática jurídica.

ABSTRACT: Since it can be noted that our legal system pressuposes a category, the ius commune, this article aims to specify its current content. After reviewing and discarding its eventual identification with the Civil Code, the general principles of law as of the Constitution, we propose as probable interpretation to relate it with legal dogmatic, as well with the concepts it has constructed and developed through the history of certain legal institutions.

Keywords: Ius commune, civil law, principles of law, Constitution, legal scholarship.

\section{INTRODUCCIÓN}

La referencia a todo ordenamiento jurídico, incluido el nuestro, importa aludir a dos características distintivas del mismo: la unidad y la coherencia, en orden a resaltar que está compuesto por un conjunto de normas que se encuentran vinculadas por alguna relación de orden que, a su vez, permite identificarlas como parte del sistema ${ }^{1}$.

Usualmente estas notas distintivas, así como el orden -ideal sistemático que permite asegurar los valores fundamentales de igualdad, certeza y seguridad jurídica ${ }^{2}$, , se dan por presupuestas, asumiéndose que siempre están presentes en el sistema jurídico ${ }^{3}$. Sin embar-

\footnotetext{
* Profesora de Derecho civil, Pontificia Universidad Católica de Valparaíso. Dirección postal: Brasil 2950, Valparaíso. Dirección electrónica: claudia.mejias@pucv.cl. Este artículo se desarrolló en la ejecución y bajo el financiamiento del Proyecto FONDECYT Regular, Nro. 1161249, titulado "Construcción dogmática de la función y alcance de la noción derecho común en el ordenamiento jurídico nacional”.

Aguiló (2000) pp. 224-230; Vergara (2014) p. 969. Los términos "sistema jurídico" y "ordenamiento jurídico", en rigor, admiten diferenciación; no obstante, para el objeto de este trabajo, se emplearán como equivalentes. En este sentido, véase Vergara (2009) pp. 228-287, y Catalano (2006) pp. 1-58.

2 Cuena (1998) pp. 11, 18-19, y Canaris (1998) pp. 25-29.

3 Cuena (1998) p. 16, y Luhmann (1983) p. 164.
} 
go, consideramos que esta premisa es un error, y adherimos a la doctrina que entiende que requieren de una confirmación que ha de fundamentarse en la esencia del derecho ${ }^{4}$.

El objetivo de este trabajo es proponer una interpretación posible, distinta de la sostenida hasta ahora por la doctrina, del contenido del derecho común. Con esta finalidad, comenzaremos colocando de relieve que nuestro ordenamiento jurídico presupone una categoría, el derecho común, a través del reenvío o aplicación que nuestro legislador hace de él. Lo anterior dota de coherencia y unidad al sistema jurídico, desde una perspectiva interna o esencial ${ }^{5}$, que le confiere flexibilidad para adaptarse a los distintos requerimientos sociales, culturales y políticos que se suscitan, sin necesidad de acudir a reformas legislativas. A continuación, revisaremos el posible contenido de esta noción, teniendo a la vista la vinculación que la doctrina ha realizado con el Código Civil, los principios generales del derecho y la Constitución Política de la República. Finalizaremos dando cuenta de nuestra interpretación, que nos conduce a la dogmática jurídica.

En atención a lo anterior, aclaramos que dejaremos de lado las diversas concepciones que tratan de definir qué es un sistema jurídico, así como la referencia a criterios lógicoformales que permiten determinar la validez de las normas y/o eliminar las contradicciones que conllevan las operaciones de aplicaciones del derecho ${ }^{6}$.

\section{EL DERECHO COMÚN COMO ELEMENTO QUE DOTA DE COHERENCIA Y UNIDAD AL ORDENAMIENTO JURÍDICO}

Nuestro legislador realiza constantemente una remisión al derecho común. En lo que sigue, pondremos de manifiesto cómo esto se expresa en diversas áreas del derecho. Desde esta perspectiva, resulta claro que asume la existencia de una categoría que denomina derecho común. La situación problemática se produce porque no resulta prístino su contenido: ¿cuál es el derecho común al que nos reenvía? Con la finalidad de responder esta pregunta, indagaremos si existe algún criterio que proporcione la normativa legal vigente.

4 Canaris (1998) pp. 22-23. Similar, Coing (1981) pp. 105-106. Por su parte, Hernández (1981) pp. 2330, indica que para Kant la unidad está en función de la idea como a priori, mientras la ciencia dogmática acoge más bien una noción organicista de unidad. Cuestiona también el postulado de plenitud del orden jurídico, aunque desde la perspectiva de la lógica, Cossio (1939) p. 17.

5 La referencia a una categoría que dota de coherencia interna al sistema jurídico se asemeja a la noción de sistema interno, porque él representa la coherencia racional y valorativa, que es inherente al derecho en cuanto tal y que este necesita para funcionar adecuadamente, CuEna (1998) p. 35. A propósito del sistema interno de los juristas romanos, Wieacker entiende por tal una estructura de entidades que: 1) comprende todos los elementos de su clase; 2) hacia afuera es autárquico y 3) hacia adentro, en cuanto a sus elementos, puede ser coherente y consistente. WIEACKER (1988) pp. 13-14.

6 Cfr. NúN̄EZ (2002) pp. 3-35. En esta dirección, De los Mozos alude a la "sistemática interna" y hace presente que la dimensión normativa no es la única ni la más válida para conseguir la unidad jurídica, DE LOS Mozos (2006a) pp. 160-166. Sin embargo, no debe perderse de vista que la actividad de la ciencia jurídica, su labor sistematizadora, tiene componentes lógicos: es un razonamiento que se califica de deductivo. VergarA (2009) pp. 288-289. En este artículo, no interesa hacernos cargo de las distintas concepciones doctrinales sobre el sistema en el derecho (sistema axiomático o lógico-deductivo, sistema interno y sistema externo, sistema abierto y cerrado). Sobre el particular puede consultarse, entre otros, CuENA (1998) pp. 31-44 y, para un estudio acabo del tema, desde los orígenes del término y toda su evolución, Losano (2002). 


\section{A. El derecho común y su Relación con el Código Civil}

Una primera vinculación que es posible advertir con la expresión derecho común que emplea el legislador, es con la estructura del Código Civil ${ }^{7}$. Se acude a él como un cuerpo normativo portador de una legislación general y supletoria. Así acontece con la Ley sobre fomento, protección y desarrollo de los indígenas ${ }^{8}$, cuyo artículo 4 se refiere a la posesión notoria del estado civil de padre, madre, cónyuge e hijo y dispone que es título suficiente para constituir a favor de los indígenas los mismos "derechos y obligaciones que conforme a las leyes comunes, emanen de la filiación legítima y del matrimonio civil".

En otras materias como la propiedad, también se pone de relieve la relación norma general-norma especial. Así, la mencionada ley, en sus arts. 16 y 18, a propósito de las tierras indígenas y la división de los derechos comunes que se tienen, hace aplicable la costumbre de cada etnia, en los términos del art. 54 de la ley y, en subsidio, a las leyes comunes. En la misma dirección, por una parte, la ley sobre copropiedad inmobiliaria ${ }^{10}$, en su art. 38, establece que dejándose sin efecto la resolución que acoge al condominio al régimen de copropiedad inmobiliaria, la comunidad que se forme entre los copropietarios "se regirá por las normas del derecho común"; y, por otra, el art. 837 del Código de Comercio $^{11}$, a propósito de la copropiedad de naves, efectúa la misma remisión.

En los casos anteriores, el reenvío al derecho común lo es a un conjunto de derechos y obligaciones contenidos en una reglamentación concreta del CC, que se califica de general. En sede de bienes sucede algo equivalente, ya que el derecho común se relaciona con las normas de adquisición y venta de bienes muebles o inmuebles, la extinción del derecho real de dominio sobre los derechos de aprovechamientos de aguas, servidumbres, materia de legados, cesión de derechos y obligaciones que emanan de una licitación pública, modos de adquirir o, genéricamente, a la aplicación del estatuto de los bienes muebles o inmuebles ${ }^{12}$.

La responsabilidad civil es otra materia específica donde encontramos una remisión al derecho común. Destacamos, dentro de los diversos cuerpos normativos ${ }^{13}$, la reciente ley que crea el acuerdo de unión civil ${ }^{14}$. Esta ley establece el estatuto aplicable a los convivientes de hecho que deciden acogerse al régimen, regulando sus efectos personales y patrimoniales. Su artículo 20 dispone: "El conviviente civil tendrá legitimación activa para reclamar las indemnizaciones derivadas de los perjuicios a que hubiere lugar por el hecho

\section{En lo sucesivo CC.}

$8 \quad$ LEY No 19.253 de 1993.

$9 \quad$ En lo sucesivo art. o arts., por artículo o artículos, respectivamente.

10 LEY No 19.537 de 1997.

11 En lo sucesivo Cco.

12 Puede consultarse, respectivamente, con relación a las materias referidas: a) LEY No 20.385 de 2009, art. 2; b) LEY No 18.712 de 1988, arts. 4 y 14; c) LEY No 18.713 de 1988, arts. 4 y 14; d) LEY No 18.714 de 1988 , arts. 4 y 14; e) LEY No 18.290 de 1984, art. 33; f) LEY No 18.695 de 2006, art. 33; g) art. 129 del Código DE Aguas; h) Ley No 18.168 de 1982, art. 18; i) Ley No 19.857 de 2013, art. 15; j) LeY No 19.886 de 2003 , art. $14 ; \mathrm{k})$ arts. 831 y 828 del Cco.

13 En esta dirección puede consultarse: a) El Cco, art. 885 a propósito de la responsabilidad del armador; b) LeY No 18.490 de 1986, art. 15; c) La LeY No 16.744 de 1968, art. 69; d) LeY No 18.302 de 1984, art. 52.

$14 \quad$ Ley No 20.830 de 2016. 
ilícito de un tercero que hubiere causado el fallecimiento de su conviviente civil o que lo imposibilite para ejercer por sí mismo las acciones legales correspondientes, sin perjuicio de las otras indemnizaciones a que tenga derecho, con arreglo a las prescripciones del derecho común". El tenor de la disposición admite más de una interpretación, como ya lo ha puesto de relieve nuestra doctrina ${ }^{15}$, resultando oscuro el alcance del reenvío al derecho común. Por una parte, podría entenderse que conforme al derecho común son posibles otras indemnizaciones al conviviente, más allá del daño por repercusión o rebote, materia en la que la ley les reconoce ahora legitimación activa, por ejemplo, la proveniente de un seguro. Lo anterior, en teoría, podría llevar a cuestionar la legitimación del conviviente de hecho que no es conviviente civil, aunque en realidad, en el estado actual de la discusión doctrinal en materia de responsabilidad, sea esto muy difícil de sostener ${ }^{16}$. Por otra parte, la norma puede interpretarse como un reconocimiento expreso a la transmisibilidad de la acción por daño moral, o incluso que se establecen reglas especiales en materia de representación que alteran las generales.

Lo descrito previamente refleja la problemática enunciada. El legislador acude a una categoría que denomina derecho común, pero precisar su real contenido va más allá del reenvío a alguna disposición contenida en un cuerpo normativo al que pueda conferírsele el carácter de general. Por lo pronto, será necesario considerar las reglas básicas en materia de responsabilidad civil, que forman parte del desarrollo que la doctrina ha realizado y que son indubitadas en la materia, sea que estén directamente contenidas en el CC o se desprendan de él, tales como: todo daño que es efectivamente causado y atribuido al actuar de una persona debe ser reparado por esta, que la reparación no puede exceder del daño efectivamente causado, debiendo evitarse enriquecimientos sin causa.

En otras ocasiones, el reenvío al derecho común nos sitúa en la normativa relativa a los contratos, como legislación supletoria. Así acontece con la Ley General de Bancos ${ }^{17}$, que en su art. 87 dispone que los bancos en el ejercicio de sus facultades quedarán "sujetos a las disposiciones del derecho común, en cuanto no hubieren sido modificadas por esta ley". Por el tema objeto de la remisión, atendido el tenor del art. 86, que faculta a los bancos para desempeñar las comisiones de confianza que allí se precisa, se realiza un llamado a la aplicación de las reglas del contrato de mandato (primeramente las contenidas en el Código de Comercio y, en subsidio, las contenidas en el CC), sin perjuicio de otras generales relativas al incumplimiento contractual y sus remedios (contenidas en el libro IV del CC), que a su vez resulten supletoriamente aplicables (tales como las relativas a la interpretación e integración del contrato, la extensión del daño indemnizable, los remedios sinalagmáticos). En el ámbito contractual, extraña nos parece la alusión al derecho común conectada con la estructura de un contrato atípico, como es el contrato de servicios, que carece de una regulación sistemática en el $\mathrm{CC}^{18}$, dificultándose comprender cómo se concretaría la aplicación supletoria de un cuerpo normativo que como tal no existe. En esta

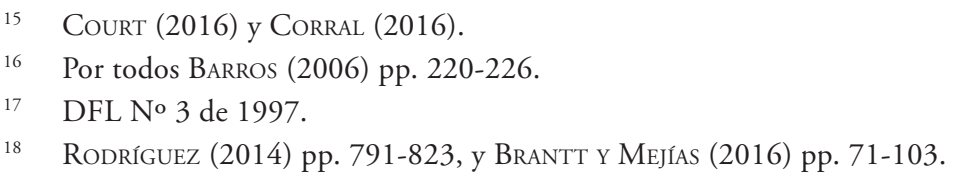


dirección, la ley que modifica la subvención escolar preferencial ${ }^{19}$ dispone, en su art. 8 bis, que "[l]a contratación a que se refiere este inciso se regirá por las normas del decreto con fuerza de ley $\mathrm{N}^{\circ}$ 1, de 1997, del Ministerio de Educación, del Código del Trabajo o por las normas del derecho común, según corresponda”.

A partir de los textos mencionados, es fácil advertir el papel que nuestro sistema asigna al derecho común: una categoría que se aplica supletoriamente. Sin embargo, aun asumiéndose que el CC es portador en sí de un derecho común, queda por precisar su contenido: ¿La referencia es a todo el CC o solo a alguno de sus artículos?, ¿qué acontece si no existe un correlato necesario en alguna materia del CC porque estamos ante una figura atípica?, ¿es más bien un llamado a aplicar categorías construidas a partir del CC?, ¿es una remisión a los principios que subyacen a estas disposiciones?, ¿`u rol se limita a proporcionar una legislación supletoria? En la sección siguiente, intentaremos responder estas interrogantes.

\section{B. El derecho común y su Relación con otros Códigos}

Nuestro legislador no reserva la expresión derecho común exclusivamente para remitirnos al CC, sino que la extiende al ámbito procesal, sea al Código de procedimiento civil, sea al Código Orgánico de Tribunales. En efecto, el art. 11 de la ley sobre comunidades agrícolas $^{20}$ indica que la reserva de derecho y acciones relativas al inmueble y a los derechos de aprovechamiento de aguas "deberán ejercitarse de acuerdo con el derecho común en el plazo de un año" y contiene, más adelante en la disposición, la referencia al pronunciamiento de los "tribunales ordinarios de justicia de acuerdo al derecho común". Por su parte, el art. 1240 del Cco, a propósito del comercio marítimo, estable que "las disposiciones de este párrafo no excluyen el ejercicio de otras medidas cautelares del derecho común". La Ley relativa a las microformas y sus reproducciones ${ }^{21}$ dispone, en su art. 3, que se sujeta su impugnación a las reglas de derecho común establecidas para los documentos.

\section{El DERECHO COMÚN COMO UNA REFERENCIA ABIERTA}

Finalmente nos interesa destacar algunas disposiciones que, si bien no aclaran el contenido de la noción derecho común, resaltan que se trata de una categoría implícita en nuestro ordenamiento jurídico o alteran el rol supletorio que, tradicionalmente, se le asigna a la normativa general respecto de la especial.

En el primer caso, nos encontramos con la Ley de Bases sobre Contratos de Suministro y Prestación de Servicios ${ }^{22}$. Su art. 4 precisa quiénes pueden contratar con la administración: "Las personas naturales o jurídicas, chilenas o extranjeras, que acrediten su situación financiera e idoneidad técnica conforme lo disponga el reglamento, cumpliendo con

\footnotetext{
19 LEY No 20.550 de 2011.

$20 \quad$ DFL No 5 de 1968.

21 LEY No 18.845 de 1989.

22 LEY No 19.886 de 2003.
} 
los demás requisitos que este señale y con los que exige el derecho común”23. En atención a que la referencia es a las personas jurídicas, se amplía el conjunto de disposiciones que pueden ser aplicadas, en atención a los requisitos que exige el derecho común; por mencionar algunos ejemplos: CC, Cco, la Ley No 20.500 y toda la normativa especial aplicable a las sociedades, entre otros.

En el segundo caso, nos parece relevante destacar dos cuerpos normativos. Por una parte, el Código Tributario, del cual se desprende que el derecho común puede estar contenido en leyes generales y especiales. En efecto, su art. 2 dispone que "en lo no previsto por este Código y demás leyes tributarias, se aplicarán las normas de derecho común contenidas en leyes generales o especiales". Tal como adelantáramos, esto llama la atención porque, incluso desde una perspectiva histórica, lo propio del derecho común es su generalidad, que permite darle un carácter supletorio, lo que difícilmente podría predicarse, sin más, de las leyes especiales. Se reafirma en esta disposición que el derecho común no se identifica con un conjunto de normas que forman parte de una rama o área del derecho.

Por último, nos interesa destacar el Código Aeronáutico, porque expresamente distingue entre el derecho común y los principios generales del derecho, presentándose como categorías diferentes. Su art. 6 señala que "[e]n lo no previsto en este código ni en los convenios o tratados internacionales aprobados por Chile, se aplicarán las normas del derecho común chileno, los usos y costumbres de la actividad aeronáutica y los principios generales de derecho". Esta disposición nos parece de extremada utilidad pues, como veremos a continuación, entendemos que el derecho común y los principios generales del derecho no son nociones que logren identificarse, de manera que su contenido no se agota a una remisión a los principios generales del derecho.

El escenario expuesto -diversos casos en que el legislador nos remite expresamente al derecho común- nos permite dar cuenta de que nuestro legislador asume una categoría implícita en todo el ordenamiento jurídico. A aquello que identifica con el derecho común, le confiere un carácter supletorio -en leyes generales o especiales- $y$, en ciertos supuestos, un papel integrador. Su real contenido, sin embargo, no resulta claro de la lectura de las disposiciones concernidas. Esto es lo que se pretende dilucidar en el apartado siguiente.

23 De manera similar, encontramos otras disposiciones: i) La LEY No 20.392 de 2009, que modifica el estatuto orgánico de CODELCO, para establecer que esta corporación "se regirá por las normas de la presente ley y por la de sus Estatutos y, en lo no previsto en ellas y en cuanto fuere compatible y no se oponga con lo dispuesto en dichas normas, por las normas que rigen a las sociedades anónimas abiertas y por la legislación común, en lo que le sea aplicable"; ii) El art. 4 de la LEY No 18.605 de 1987, que crea los Consejos Regionales de Desarrollo, dispone que "se entenderá por sector privado, para los efectos de esta ley, el constituido por entidades que realicen actividades regidas por el derecho común, cuya administración no esté intervenida por el Estado o sus organismos, como asimismo por aquellas en que el Estado o sus empresas, sociedades o instituciones solo tengan aportes de capital, representación o participación minoritarios”; iii) Finalmente, el art. 167 del Código de Minería dispone que "[l] os contratos relativos a concesiones mineras o sustancias minerales se sujetarán a las normas del derecho común, salvo en cuanto estas aparezcan modificadas por este Código”. A propósito de las concesiones mineras, art. 3 de la LEY No 18.097 de 1982, dispone que: "[n]o se consideran sustancias minerales las arcillas superficiales, las salinas artificiales, las arenas, rocas y demás materiales aplicables directamente a la construcción, todas las cuales se rigen por el derecho común o por las normas especiales que a su respecto dicte el Código de Minería”. 


\section{EL ALCANCE DE LA NOCIÓN DE DERECHO COMÚN}

Una primera aproximación para entender qué es el derecho común nos lleva, por razones históricas, a vincular esta noción con el contenido del CC. Sin embargo, esta función de coherencia y unidad del sistema, en último término para la doctrina, ha descansado también en los principios generales del derecho, incluso en el texto de nuestra Constitución. Por nuestra parte, creemos que la noción importa una clara remisión a la dogmática jurídica. En las líneas que siguen, desarrollaremos estas ideas.

\section{A. La nOCión de derecho común y el contenido del Código Civil}

La identificación derecho civil y derecho común tiene orígenes históricos. La expresión derecho común se remonta al derecho romano, mas es en la Edad Media que se consolida gracias a la ciencia jurídica de la época. Ya en el siglo XIV, Bartolo de Sassoferrato propagaría definitivamente esta identificación ${ }^{24}$. Nos parece importante destacar que en la Edad Media, la del derecho común europeo, la nota distintiva de este derecho era científica y no legal; en palabras de Grossi, la confianza estaba en la interpretatio, que se refería no a la exégesis de los textos romanos sino a la "reapropiación y reconsideración, bajo la protección de los textos romanos, de todo un orden jurídico, de un orden de valores jurídicos que aflora (...) bajo el aspecto de la aequitas ${ }^{25 "}$; más adelante en su obra, precisa que con este término se alude al "complejo ordenado y armónico de principios, reglas e instituciones que, más allá de las formas jurídicas, se puede encontrar en las mismas cosas, si observamos con ojos humildes y atentos" 26 .

El derecho civil contenido en el CC ha sido el resultado del proceso codificador. Es sabido que el fenómeno mismo de la codificación se presentó como una noción moderna de sistema jurídico, pues contiene un conjunto coherente de normas, deducidas de principios generales que se organizan sistemáticamente a través de estos textos escritos ${ }^{27}$; mencionándose como rasgos definitorios: la unidad del orden jurídico, la completitud, ausencia de lagunas, organización racional de las normas, conceptos y principios bajo el presupuesto de coherencia que proporcionan las operaciones de orden lógico -inducción y deducción- ${ }^{28}$. De allí entonces que resulte natural la asimilación que se ha hecho del CC con el papel que históricamente cumplió el derecho común. Incluso la doctrina suele calificar a este Código

\footnotetext{
24 Calasso (1954) pp. 368-375.

25 Grossi (1996) p. 36. El autor más adelante hace presente que Dios es garantía de este orden armónico y la equidad es la dimensión ordenadora, p. 180, pp. 225 y ss.

26 El autor afirma que, en la ciencia jurídica medieval, la aequitas está en los hechos -en la naturaleza de las cosas, es decir, en una realidad objetiva que lleva la impronta benéfica y providencial de Dios-, donde ya es derecho pero espera ser transportada, traducida, interpretada, reducida a preceptos. Grossi (1996) pp. 147, 181187. Con relación a la ciencia, esta se identificará cada vez más por su sociabilidad, porque el saber elaborado alcanza su articulación indefectiblemente dialéctica (pp. 155-157).

En la misma dirección, Pérez Martin afirma que el derecho común es sobre todo un producto de las Universidades, una elaboración de los juristas. Pérez (1999) p. 79; con relación a la lógica, la dialéctica y la tópica en la construcción de la ciencia jurídica en la Edad Media, pp. 86-91.

27 Cuena (1998) pp. 21-24.

28 Cuena (1998) p. 23. Sève (1986) pp. 78-84 da cuenta de esto aunque el autor no comparte esta visión.
} 
como el derecho privado común y general. Común en el entendido de que todas aquellas relaciones jurídicas privadas de las personas, que no estén regidas por otra rama especial o autónoma del derecho, lo están por el derecho civil; y general, porque regula las relaciones jurídicas ordinarias y más usuales del ser humano ${ }^{29}$.

El carácter común del CC, que se manifiesta también en su generalidad ${ }^{30}$, se ha visto, con el tiempo, afectado por la especialidad de las normas de derecho privado, lo que se ha materializado básicamente por dos vías. Por una parte, por la dictación de leyes que vienen a complementar o incorporar a la regulación civil, materias no previstas por el CC; y por otra, por la creación de ramas del derecho que descansan en principios doctrinarios distintos al romano y francés que inspiraron a nuestro CC. Nos situamos, actualmente, en una época que la doctrina ha denominado la época de la postcodificación o la edad de la descodificación, caracterizada por la incorporación a través de esta legislación de un sinnúmero de instituciones y/o figuras cuya vinculación con el derecho codificado no resulta claro $^{31}$, sin que la solución pase por pretender dar primacía a la aplicación de la legislación especial.

Conforme hasta lo ahora dicho, el derecho civil está contenido en el CC y en diversas leyes especiales. De este conjunto de normas, que componen el derecho civil, la doctrina suele atribuir solo al CC la función de constituir un ordenamiento supletorio llamado a ser aplicado en caso de vacío o lagunas legales y de dotar de unidad y coherencia al sistema jurídico $^{32}$. De esta forma, la referencia al derecho común vinculada con el cuerpo del CC, lo es a una legislación que por sus características de generalidad se aplica supletoriamente. Este rol también es histórico, como ha afirmado autorizada doctrina; en la Baja Edad Media, surge con la finalidad de conciliar la aplicación del derecho propio con el derecho común, al reconocerse a este una supremacía que no excluía la aplicación de los otros derechos, supremacía que se manifiesta en que constituye el marco general en el cual se inserta la vigencia del derecho propio. Además, si no existe derecho propio, es el derecho común el que se aplica, reconociéndose ampliamente su carácter supletorio ${ }^{33}$.

Desde la perspectiva de la doctrina del derecho civil, no se advierte un reparo a su calificativo de derecho común; los cuestionamientos han surgido por parte de la doctrina administrativista en nuestro país ${ }^{34}$. Sin embargo, nos parece que no es posible identificar la noción de derecho común con un cuerpo normativo dado, a partir del carácter supleto-

29 Por todos Vodanovic (2005) pp. 84-85.

30 La doctrina entiende que son normas de derecho común aquellas que son dictadas para la totalidad de las personas, la totalidad de las cosas o la totalidad de las relaciones jurídicas. VODANOVIC (2005) pp. 50-51.

31 Hace presente este problema en los sistemas jurídicos latinoamericanos, GuZMÁN (2006) p. 178. En términos más amplios Donato (2005) pp. 957-966, el autor sí atribuye al Código Civil el carácter de derecho común, pp. 963-965.

32 Así, aunque no se precisa el alcance, se ha afirmado que la función integradora del derecho supletorio se explica en el caso del Código Civil por estar contenidos en él los principios informadores del derecho común. GUZMÁN (1999) p. 41; TAPIA (2005) p. 985, y BERMúdeZ (2012) pp. 57-60.

33 Sobre el particular puede consultarse en detalle GUZMÁn (1989) pp. 39-78.

34 En esta dirección, Vergara ha afirmado que se trata solo de un residuo histórico, "hoy anacrónico, cuya operatividad puede ser confundida con el antiguo papel del ius commune". Vergara (2010) p. 74. Esta postura es calificada, por la propia doctrina nacional administrativa, de minoritaria, BERMúdez (2012) pp. 65-68. 
rio que se le atribuye, porque esto no asegura la coherencia interna del sistema, ni permite brindar soluciones a los problemas prácticos que plantea la aplicación del derecho, en especial ante un vacío o laguna legal, ni hacerse cargo de los distintos requerimientos que el ordenamiento jurídico presenta ante la incorporación de diversas leyes, contenidas extracódigo que requieren de una construcción dogmática a partir de un cuerpo normativo y de sus principios rectores para poder ser aplicadas (recuérdese la situación que describíamos a propósito del art. 20 de la ley 20.830 y las diversas interpretaciones que ofrecía).

\section{B. LA NOCIÓN DE DERECHO COMÚN Y LOS PRINCIPIOS GENERALES DEL DERECHO}

Para parte de la doctrina, el sistema jurídico se justifica en "los más altos valores jurídicos, concretamente el mandato de justicia y sus concreciones en el principio de igualdad y en la tendencia a la generalidad" 35 , a lo que también se añade la seguridad jurídica. Es asimismo concebido como un sistema teleológico -referido a toda realización de fines y valores-, cuyas valoraciones básicas se encuentran en los principios generales de un ordenamiento jurídico ${ }^{36}$. De esta forma descansa en último término la coherencia y unidad del sistema en estos principios ${ }^{37} y$, por esto, se ha sostenido que "la ciencia jurídica no tiene otra misión que la de develar y descubrir, a través de conexiones de sentido cada vez más profundas y ricas, mediante las construcciones de instituciones y la integración respectiva de todas ellas en conjunto, los principios generales sobre los que se articula y debe, por consiguiente expresarse, el orden jurídico"38.

A su turno, la doctrina, al referirse a los principios generales del derecho, les otorga un carácter uniformador de todo el ordenamiento jurídico en atención a su propia naturaleza ${ }^{39}$. Es por esto que uno de los posibles alcances que puede darse a la categoría del derecho común es identificarla con los principios generales del derecho.

En lo que sigue, pretendemos demostrar que esto es insuficiente: su abstracción e indeterminación obstan a que el derecho común cumpla con la función que, expresa o implícitamente, le reconoce el sistema jurídico.

Si nos centramos en el derecho positivo vigente, advertimos dos disposiciones legales que nos remiten a estos principios. Por una parte, el Código Aeronáutico en su art. 6 -que ya mencionamos-, les reconoce expresamente un carácter supletorio ante un vacío o laguna legal, indicando explícitamente que los concibe como una categoría diferente a la del derecho común. Por otra, el CC, en su art. 24, consagra una norma final de interpretación de la ley, que conduce a aclarar su sentido y alcance conforme al espíritu general de la legislación y a la equidad; la doctrina nacional es coincidente en reconocer aquí una referencia a los

\footnotetext{
CANaris (1998) pp. 25-26.

CANARIS (1998) pp. 49-57.

En la doctrina nacional AlCALDE (2003) pp. 57 y ss; p. 251.

García (1984) pp. 34-35.

39 Martínez-Sicluna (1993) pp. 35-37. El autor expone que a partir de la obra de Federico de Castro en España se les atribuye una triple dimensión: fundamentar, interpretativa y supletoria con relación a las demás fuentes.
} 
principios generales del derecho ${ }^{40}$. El reconocimiento legal se limita a fijar el papel que se le otorga en materia de interpretación y su carácter supletorio, ante un vacío o laguna legal.

Si nos detenemos en su contenido, advertimos otras dificultades. En primer lugar, su determinación. Un punto de partida podríamos encontrarlo en su noción, sin embargo, esta usualmente se da por supuesta. La expresión principio significa, coherentemente con sus antecedentes históricos, aquello de lo cual algo procede. Es un fenómeno ideal y de naturaleza lógica a partir del cual es posible deducir otro y que no requiere de demostración. Es, en rigor, una proposición que tiene la capacidad para fundar otras posteriores y, en concreto, el ordenamiento jurídico ${ }^{41}$. La doctrina considera que es Tomás de Aquino el primero en fundar en la historia del pensamiento jurídico un esquema axiomático-científico, en el que los principios generales ocupan un lugar central, relacionándolos con la ley natural ${ }^{42}$. Lo anterior no obsta a que, en la actualidad, parte importante de la doctrina se incline por sostener que estos principios no se identifican con el derecho natural ${ }^{43}$.

Tratando de dilucidar su contenido, los autores suelen destacar su nexo con las normas jurídicas, afirmándose que los principios generales del derecho están recogidos en normas jurídicas o que estos son obtenidos a partir de ellas, a través de la inducción ${ }^{44}$, de manera que serían un instrumento de autointegración del ordenamiento jurídico. En cualquier caso, se hace evidente que no son el resultado de una mera equivalencia entre la norma jurídica y aquello que es deducido. El inconveniente se mantiene y el resultado son nociones muy amplias de los mismos. En esta dirección, Esser nos indica que son principios jurídicos que están encarnados en una institución, por un acto constitutivo del Legislativo, de la jurisprudencia o de la vida jurídica, y la forma que adoptan es la de principios sistemáticos o constructivos del derecho material, máximas o reglas técnicas, figuras fundamentales y comunes a los derechos civiles o simples reglas técnicas del pensamiento y de la labor jurídica ${ }^{45}$.

Con la finalidad de facilitar su identificación, parte de la doctrina ha proporcionado ciertas características de estos principios: principalidad, generalidad y juridicidad ${ }^{46}$; mas su enunciación no permite aportar mayor claridad en la materia. Al momento de perfilarlos, se advierte la complejidad en su formulación: hay enunciaciones "por docenas y hasta por centenares -lo que resulta contrario a su esencia de principios generales-, o bien se parte

\footnotetext{
40 Por todos, GuZMán (2011) pp. 467-469.

41 GuZMán (2014a) pp. 1-9. Con mayor detalle GuZMán (2014b).

42 GuZmán (2014b) pp. 76-77, en particular capítulo 8, pp. 69-93, y Del Vecchio (1971) p. 70.

43 Detrás, por cierto, están las concepciones positivistas o ius naturalistas de los principios. Del VeCCHIO (1971) pp. 43 y ss. El autor da cuenta de esto, sin perjuicio de que defiende esta vinculación. En los mismos términos GARCía (1984) pp. 60-64. En la doctrina nacional, mantiene la relación con el derecho natural ALCALDE (2003).

44 Sin perjuicio de esto, parte de la doctrina considera que los principios son irreductibles a normas, véase MarTínez (1993) pp. 92 y ss. Para las corrientes fundadas en el derecho natural, se obtienen por medio de la deducción. Similar, Tardío (2011) pp. 44-47.

45 ESSER (1961) pp. 169-171.

46 Así Mans (1979) pp. XXVI- XXVIII. El autor, con relación a la primera de estas características, nos indica que la referencia es al fundamento, causa u origen. Con la segunda, la referencia es a un género en oposición a especie. Y la última, para referirse a ella -la juridicidad- en sus múltiples aspectos y facetas.
} 
de escuetos enunciados excesivamente abstractos o genéricos (en el sentido porfiriano del género) que le resta la debida eficacia en su aplicación" ${ }^{37}$.

Por todo lo anterior, la doctrina ha hecho presente que a propósito de estos se incluyen: axiomas, máximas que los autores proponen, ideas dominantes en un sistema jurídico nacional, principios abstractos en los que se inspira una institución universal, principios que se derivan como la ratio de determinadas disposiciones vigentes en el ordenamiento jurídico, principios propios de la aplicación del derecho y principios superiores que informan todo el derecho ${ }^{48}$. En trabajos recientes, la tendencia que hemos advertido es a identificarlos con ciertos brocardos que, en último término y en varias ocasiones, son portadores de máximas que se remontan al derecho romano ${ }^{49}$.

Nos parece que el verdadero énfasis de la doctrina más reciente ha estado en examinar las diversas funciones que cumplen. Así se les considera: i) fuente de nuevo derecho al crearse una disciplina jurídica a partir de estos, para realidades no reguladas; ii) herramienta de hermenéutica legal para precisar el alcance de una disposición, que es ambigua o contradictoria; y, iii) criterio de censura o crítica si se encuentra que está en contradicción con la norma ${ }^{50}$.

Entendemos que, en el estado actual de la materia, no es posible hacer descansar autónomamente en los principios generales del derecho el rol de coherencia interna del sistema jurídico debido al alto grado de abstracción e indeterminación de su contenido. Dificultad que, como indicáramos, también está presente en su identificación; no resulta pacífico en la doctrina arribar a principios que, como su nombre lo indica, puedan considerarse generales a todo el ordenamiento jurídico. La excepción la constituye indubitadamente el principio de la buena fe. Compartimos la opinión que se niega a calificar de principios generales del derecho a aquellos principios propios de ciertas áreas de especialización o ramas del derecho, por resultar contrarios a su propia estructura, como portadores de una ratio iuris de carácter universal ${ }^{51}$. De esta forma, no es posible identificar la categoría del derecho común con estos. Tampoco debe perderse de vista el obstáculo legal que constituye el art. 6 del Código Aeronáutico.

\footnotetext{
47 ARCE (1990) p. 51.

48 Por todos, Esser (1961) pp. 4-5. Similar, Tardío (2011) pp. 9-17.

49 Así, por ejemplo, Mans (1979) pp. XXVI- XIX, afirma que los principios del derecho deben buscarse en el derecho romano y en el derecho canónico. NúNEz (2000) pp. 37-60 ha afirmado que con estos principios entran en la escena jurisdiccional máximas del antiguo ius commune, y así derecho europeo y derecho común tienen una raíz romana. La autora sí atribuye una tarea fundamental a la doctrina y jurisprudencia en la armonización del derecho dentro del ámbito europeo. En esta dirección De los Mozos (2006b) pp. 206-207. En el mismo sentido, un número importante de trabajos vinculan principios que se entienden "generales", por ejemplo, la protección de la parte más débil, la responsabilidad de los padres, la equidad, con orígenes en el derecho romano, véase DARío (2014).

50 Guzmán (2014a) pp. 8-9, Del Vecchio (1971) pp. 61 y ss., Sánchez de la Torre (1993) pp. 15, 20, y TARDío (2011) pp. 119-155.

51 Del Vecchio (1971) pp. 87, 233, y Arce (1990) pp. 64-65. En contra, García (1984) pp. 63-64, y Mans (1979) pp. XXVI-XXVII.
} 
En definitiva, la importancia que los principios generales del derecho tienen en la ciencia jurídica está indisolublemente vinculada a la labor que la dogmática realiza a partir de ellos, ya sea para intentar precisarlos y/o atribuirles las funciones ya mencionadas ${ }^{52}$.

\section{La noción de derecho común y la Constitución Política de la República}

Hemos constatado que, desde una perspectiva práctica, nuestra doctrina ha conferido el papel de dotar de coherencia interna al ordenamiento jurídico, a partir del fenómeno de la constitucionalización del derecho, a la Constitución Política de la República ${ }^{53}$. En esta dirección, Natalino Irti ha afirmado que, detrás de la aparente unidad del sistema jurídico, existe una pluralidad de subsistemas que no forman parte de un sistema más amplio; a lo sumo conforman un polisistema cuya unidad es solo asegurada por la Constitución, que constituye el vértice de la pirámide normativa ${ }^{54}$.

Nuestros autores desprenden la existencia de principios y valores rectores del ordenamiento jurídico nacional del texto de la Constitución y, en particular, de los derechos fundamentales que consagra; principios y valores que tienen un carácter supletorio, con una característica peculiar, en atención a su fuente, se predica su superioridad jerárquica ${ }^{55}$. Lo anterior ha conducido, por ejemplo, en el derecho civil, a reforzar una noción amplia y objetiva de daño moral para identificarlo y comprender la lesión a los derechos de la personalidad o para admitir su procedencia en el ámbito de la responsabilidad contractual, esgrimiéndose en ambos casos el respeto de las garantías constitucionales (igualdad ante la ley, derecho al honor y la vida privada, entre otras ${ }^{56}$. La consideración de los textos constitucionales, como instrumentos portadores de valores, ha llevado incluso a parte de los autores a plantear la existencia de un derecho "constitucional" común latinoamericano, al proporcionar estos textos un bloque normativo común, a partir del nexo con los derechos humanos. En este contexto se ha indicado que la generalidad que en algún momento se predicó del derecho común, ahora descansa en los textos constitucionales de los países latinoamericanos ${ }^{57}$.

52 García (1975) pp. 333-334.

53 Acerca de la función normativa que la doctrina y la jurisprudencia ha dado a la Constitución, véase ALDUNATE (2009) pp. 445-452. En similares términos, refiriéndose a Francia, FAVOreu (2001) pp. 41-42. Parte de la doctrina lo ha calificado directamente como el nuevo derecho común por una serie de razones: i) regula materias que interesan a todo el ordenamiento jurídico, como la elaboración de las leyes; ii) su incidencia en el sistema de fuentes; iii) incidencia de los derechos fundamentales; iv) rol del Tribunal Constitucional como intérprete supremo que asegura coherencia al resto del ordenamiento. Cfr. Fernández-Carvajal (1989) pp. 257 264.

54 Cfr. IrTi (1979) pp. 25, 65 y 72.

55 Aldunate (2009) p. 478, y Squella (2011) pp. 311-313, 315-317. En la doctrina civil, puede consultarse Pizarro (1998), y TAPia (2007).

56 Por todos, véase Domínguez (2009). En la doctrina civil han ahondado en esto Corral (2004) pp. 47-63, el autor sí precisa en su artículo que se opone "a que se instaure una autarquía constitucional que prescinda de la función de derecho común que se ha reconocido al Derecho privado y, por sobre todo, al Código Civil, sin el cual la misma Constitución resulta difícilmente comprensible”. DomínguEz (1996) pp. 107-137, el autor da cuenta del empleo de la Constitución para amparar instituciones esenciales a la persona, cuyo fenómeno se conoce con el nombre de constitucionalización del derecho civil.

57 Corzo (2014) pp. 4-5, y Von Bogdandy (2014). 
El fundamento de esta postura radica, entre nosotros, en la aplicación directa de la Constitución y en la interpretación conforme a ella. En concreto, a partir del art. 6 inciso $2^{\circ}$, que dispone: "Los órganos del Estado deben someter su acción a la Constitución y a las normas dictadas conforme a ella, y garantizar el orden institucional de la República. Los preceptos de esta Constitución obligan tanto a los titulares o integrantes de dichos órganos como a toda persona, institución o grupo". En atención a este precepto, se afirma que las disposiciones constitucionales son verdaderas normas jurídicas y no solo normas que contienen programas o principios; son, por ende, obligatorias y pueden aplicarse inmediatamente para resolver la controversia ${ }^{58}$. En este punto conviene recordar que, tras la entrada en vigencia de la Constitución de 1980, la doctrina constitucional se ha inclinado por afirmar que los principios constitucionales son vinculantes con independencia de que la norma fundamental se remita a la ley, precisamente porque obligan a todo integrante de la comunidad nacional; no se trataría de programas, planes y proyectos que requieran de un desarrollo normativo ${ }^{59}$. Por otra parte, a partir de la interpretación conforme a la Constitución, se sostiene que el órgano jurisdiccional encargado de resolver una cuestión debe optar, en un caso de interpretación, por aquella que resulte más conforme a la Constitución ${ }^{60}$.

El problema técnico jurídico que se advierte, al hacer residir en la Constitución el papel que tradicionalmente ha cumplido el derecho común, es el de la disminución de la fuerza normativa del propio texto de la Constitución, al asumirse que sus disposiciones, a las que constantemente se hace referencia, son portadoras de un contenido que no se desprende realmente de su texto o que contienen principios y valores cuya determinación queda, en definitiva, entregada al arbitrio del intérprete ${ }^{61}$. Este alcance, que no se comparte, en más de una ocasión ha sido suscrito por nuestro Tribunal Constitucional. Así, ha sostenido que: i) "Los principios y valores establecidos en la Constitución no configuran meras declaraciones programáticas, sino que constituyen mandatos expresos para gobernantes y gobernados, dada la fuerza obligatoria de los preceptos constitucionales en virtud de lo dispuesto en el artículo 60"62. ii) El contenido del artículo 19 CPR, conjuntamente con sus

\footnotetext{
58 Aldunate (2009) p. 446, y Cordero (2009) pp. 26-27.

59 Cfr. Bulnes (1998) pp. 139-140, y Favoreu (2001) p. 35.

60 Lo anterior, sin perjuicio de que si la normativa infraconstitucional no se ajusta al texto constitucional, sea solo el Tribunal Constitucional el órgano que puede declarar la inaplicabilidad del precepto (art. 93 No 6 de la Constitución). Por todos, Bordalí (2007) pp. 529. Más adelante, el autor afirma (pp. 535-536) que, con la finalidad de uniformar las decisiones sobre derechos fundamentales, los tribunales ordinarios debiesen seguir las líneas de interpretación sostenidas por el tribunal constitucional. En contra -aunque previo a la reforma del 2005-, entendiendo que cualquier tribunal debe dejar de considerar un precepto que sea contrario a la Constitución, FERNÁNDEZ (2001) pp. 97-98.

61 Aldunate (2009) pp. 455 y ss. Mismo sentido, Alcalde (2008) pp. 463-484, en especial p. 476. Similar, De los Mozos (2006b) p. 207. Esto difiere de la Constitución Española, que en su artículo $1^{\circ}$ propugna "como valores superiores de su ordenamiento jurídico la libertad, la justicia, la igualdad y el pluralismo político" y que conlleva a la doctrina a afirmar la existencia de unos valores supralegales de justicia. Cfr. GordiLLO (1988) pp. 500 y ss; precisamos sí que el autor entiende que la Constitución cumpliría ahora el rol que históricamente cumplió el derecho natural. Acerca de la importancia de estos valores en la formulación de los principios generales del Derecho, véase García (1984) pp. 91-110, 133, y ArCE (1990) pp. 93 y ss.

62 Control de Constitucionalidad, Rol No 46, considerandos 19-21. Requerimiento, Rol No 280. Art. 2331 del CC, Rol No s 1185, 2410, 2747 2801, 2860, 2887.
} 
artículos $1^{\circ}, 4^{\circ}$ y $5^{\circ}$, inc. $2^{\circ}$, configuran principios y valores básicos de fuerza obligatoria que impregnan toda la Constitución de una finalidad humanista que se irradia en la primacía que asignan sus disposiciones a la persona humana, a su dignidad y libertad natural, en el respeto, promoción y protección a los derechos esenciales que emanan de la naturaleza humana, que se imponen como deber de los órganos del Estado ${ }^{63}$. iii) Y a propósito de la interpretación conforme a la Constitución: "Deben desecharse las interpretaciones constitucionales que resulten contradictorias con los principios y valores rectores. Así frente a diversas interpretaciones posibles del alcance de la protección constitucional de un derecho fundamental, debe excluirse la que admita al legislador regular su ejercicio hasta extremos que en la práctica imposibiliten la plenitud de su vigencia efectiva o compriman su contenido a términos inconciliables con su fisonomía"64.

Se asume, por lo tanto, que la Constitución es portadora de principios y valores, con independencia de que cuenten con una consagración expresa en el texto constitucional. Sin embargo, como ha puesto de relieve Aldunate, esto implica dejar entregado al intérprete constitucional, a través de un procedimiento de ponderación, la determinación de las soluciones concretas que se puedan dar a las eventuales colisiones entre dichos principios y valores. La consecuencia es, precisamente, la imposibilidad de fundar en el texto constitucional el criterio utilizado para darle solución ${ }^{65}$. Lo anterior también se proyecta en la interpretación conforme a la Constitución y, por esto, el autor referido afirma-postura que compartimos- que el sentido original del tópico de la fuerza normativa de la Constitución importa una contención y no una ampliación de contenidos normativos construidos teóricamente o a través de la interpretación del texto de la Constitución ${ }^{66}$.

Tampoco debe perderse de vista que esta forma de comprender y atribuir un contenido al texto constitucional prescinde del desarrollo de la dogmática constitucional. Asumiendo la eficacia directa de la Constitución, reconoce que existen normas que, sin requerir mediación por parte de otra disposición jurídica, ni siquiera complementaria, deben ser aplicadas. No se produciría un inconveniente en el sistema jurídico porque, para darles vigencia, el órgano encargado de aplicarlas puede acudir "a las normas de derecho común o, en último término a los principios y reglas generales del derecho" ${ }^{17}$. Se puede advertir que parte de la propia doctrina constitucional considera y presupone la existencia de un derecho común, que logra dotar de coherencia interna al ordenamiento jurídico, que no se identifica con la Constitución. Además, no debe perderse de vista que esta ha denunciado la ausencia de desarrollo del contenido de los derechos fundamentales, de manera que se carece de un marco disciplinar que permita precisar sus contornos y alcance, a diferencia de lo que acontecería si se acude directamente a la dogmática jurídica de cada área del derecho $^{68}$. Nos permitimos un ejemplo para graficar lo anterior. Tratándose del daño moral y la

63 Art. 2331 del CC, Rol No 1185, considerandos 11 y 12. En el mismo sentido Art. 2331 del CC, Rol Nos 2410, 2747 2801, 2860, 2887.

64 Art. 2331 del CC, Rol No 1185, considerando 13.

65 Cfr. Aldunate (2009) pp. 456-457.

66 Cfr. Aldunate (2009) pp. 463-471.

67 Fernández (2001) p. 79.

68 Aldunate (2001) pp. 21-22. 
extensión de su noción, a partir del texto constitucional -como adelantáramos- se ha sostenido que las personas jurídicas pueden sufrir un daño extrapatrimonial, una vez superada la noción de pretium doloris ${ }^{69}$. En la materia, puede advertirse una cierta tendencia por parte de nuestros tribunales, para probar su existencia, de exigir que este daño haya producido consecuencias patrimoniales ${ }^{70}$. Lo anterior refleja que la construcción solo a partir de principios y valores, contenidos expresa o implícitamente en la Constitución, puede introducir un elemento distorsionador en la noción de daño extrapatrimonial, que en sí está referida a la persona misma o a sus intereses extrapatrimoniales ${ }^{71}$. A partir del derecho que consagra nuestra Constitución, se afirma algo que esta no dice en idénticos términos ${ }^{72}$, la existencia de un derecho al honor y a la imagen, y que la sola infracción de estos derechos da lugar a resarcimiento, abriéndose paso a una serie de interrogantes cuya respuesta no está en el texto de la Constitución: ¿̇toda persona jurídica puede realmente sufrir un daño al honor o la imagen? Detrás de esta exigencia, ¿se encubre la indemnización de un lucro cesante no probado? Por nuestra parte, creemos que la respuesta exige considerar principalmente la naturaleza jurídica atribuida a la personalidad jurídica, es decir, si la persona jurídica de que se trata encuentra su naturaleza en la teoría de la ficción, realidad o institución, aspecto que no podemos abordar en esta oportunidad. El ejemplo nos permite sostener que el contorno y alcance del derecho que se obtiene de la Constitución, viene dado no por su incorporación en el texto constitucional, sino por el desarrollo dogmático que brinda la propia disciplina; es esta la que realmente confiere las reglas que podrán aplicarse para solucionar el problema concreto. En las líneas que siguen, desarrollaremos esta relación.

\section{LA NOCIÓN DE DERECHO COMÚN Y LA DOGMÁTICA JURÍDICA}

Luego del análisis formulado puede advertirse la existencia de un derecho común que se conecta con la dogmática jurídica, es decir, con la construcción que efectúa la ciencia del derecho positivo vigente.

Los antecedentes históricos de esta categoría nos llevan a una primera vinculación con el CC chileno. Sin embargo, resulta evidente la insuficiencia de este cuerpo normativo para dotar de coherencia a todo el sistema jurídico. Esto ya se advierte en la remisión que nuestro legislador hace del derecho común, que excede del contenido del Código Civil, sea porque nos reenvía a otros cuerpos normativos, sea porque no hay realmente una regulación concreta que pueda aplicarse supletoriamente a partir de él o porque aplicar efectivamente la disposición presupone considerar principios e instituciones que han sido desarrollados previamente por la dogmática jurídica. Se destaca sí una característica atribui-

\footnotetext{
69 Barros (2006) pp. 297-301, y Corral (2013) pp. 153-154.

70 En esta dirección, por ejemplo, ZORÍN CON COMPAÑIA (2012). SOCIEDAD CON BANCO SANTANDER (2015), Sociedad Con ARriagada (2011), Clínica con Meza (2009), Industria con BBVA (2008). Interesante voto de minoría reconoce el problema denunciado SOCIEDAD CON YOSHIO (2010).

71 Corral (2013) pp. 149-150.

72 El artículo 19 No 4 de la Constitución asegura a todas las personas “4․ El respeto y protección a la vida privada y a la honra de la persona y su familia”.
} 
da desde sus orígenes: su nota distintiva fue científica y no legal ${ }^{73}$. La identificación con los principios generales del derecho, de manera autónoma, tampoco permite al derecho común cumplir su función, en materia de interpretación e integración, al interior del ordenamiento jurídico; su trascendencia en este contexto aparece ligada al trabajo que la doctrina efectúa a partir de estos, para descubrir las máximas o reglas fundamentales de la respectiva institución. Finalmente, como indicáramos, la Constitución tampoco es la llamada a cumplir con esta tarea, no está concebida como un instrumento portador de principios y valores que debidamente explicitados permitan uniformar el sistema jurídico. Su propio contenido presupone al derecho común y la tarea que desarrolla la dogmática jurídica.

Nos parece importante precisar que, al aludir a la expresión dogmática jurídica, nuestra referencia trasciende a los orígenes del término ${ }^{74}$. Desprendida de su conexión histórica, como lo han señalado otros autores, "puede ser utilizada para designar la comprensión sistemática del contenido de un determinado ordenamiento jurídico"75.

La dogmática jurídica nos aporta una comprensión sistemática de cada una de las instituciones presentes en nuestro ordenamiento jurídico. En su tarea de examen y análisis de estas, a lo largo de su evolución, ha arribado a un conjunto de reglas y principios que constituyen el acervo jurídico en la materia. De esta forma, la noción de derecho común en la actualidad importa una referencia a este acervo jurídico común. En él se apoya toda posible nueva construcción dentro del sistema, actuando como su fundamento y límite. Es a partir de este acervo que se proporcionan soluciones coherentes al interior del sistema y se fijan los límites de las posibles soluciones que el ordenamiento jurídico soporta.

Es sabido que, en la base del conocimiento sistemático y racional de los fenómenos jurídicos, se encuentra la investigación y el método que la doctrina emplea, que no se limita solo a la determinación de la conexión de las normas jurídicas, desde una perspectiva deductiva, y delimitación de su ámbito de vigencia. Su tarea ha sido más bien de construcción, a partir de reglas y principios en los que se apoya y, por esto, se ha afirmado que la dogmática jurídica constituye el plano más elevado y más abstracto de las posibles determinaciones de sentido del derecho dentro del propio sistema jurídico ${ }^{76}$.

Las reglas que conforman este acervo común son conocidas y asumidas por los especialistas de cada área o rama del derecho, y se transforman en los límites indispensables de su reflexión. Su conocimiento lo proporciona el análisis histórico de la institución. De esta

\footnotetext{
73 Por todos, Pérez (1999) pp. 69-91. En esta dirección no debe perderse de vista que reiteradamente se ha señalado que la confluencia del derecho romano y canónico no obedeció solo a sus textos sino también a la doctrina elaborada a partir de estos, destacando la labor de glosadores y comentaristas, pues en definitiva su trabajo apuntaba a dotar al texto de significado cierto y claro en el primer caso, y de construcción jurídica y debate doctrinal en el segundo. De allí que suela afirmarse que ius commune radicaba en la obra de los juristas. Por todos WiEAcKer (1998).

74 Su nombre (Rechtsdogmatik) corresponde a una determinada concepción del derecho, la jurisprudencia de conceptos, desarrollada en Alemania en el siglo XIX.

75 Coing (1982) p. 106. Misma dirección, Bernasconi (2007) p. 15, y Aarnio (1985) p. 180.

76 LuHMann (1983) p. 34
} 
forma, es la propia dogmática jurídica, como se ha sostenido, la que define las condiciones de lo jurídicamente posible ${ }^{77}$.

Estas reglas de derecho común están a la base de cada una de las áreas o ramas del derecho, incluso algunas son de carácter transversal, de manera que no limitan su campo de aplicación al derecho privado o al derecho civil, sino que se extienden a todo el ordenamiento jurídico. Ciertamente su impacto es diferenciado por el alcance mismo que tienen las tareas de interpretación e integración en el derecho público y en el derecho privado, considerando sus propios principios rectores (principio de legalidad vs. principio de autonomía privada). Estas reglas pueden emanar de una rama que consideremos general o especial del derecho, y su sustrato puede estar contenido en reglas de general o particular aplicación.

Su ámbito de vigencia, por tanto, se proyecta a todo el ordenamiento jurídico, sin que pueda negarse su aplicación, porque su sustrato positivo corresponde a una determinada rama del derecho. Así, por ejemplo, las reglas de derecho común en materia de prescripción, cuyo sustrato se apoya, en parte, en las reglas del CC, se aplican a áreas del derecho público $^{78}$. Lo anterior no implica obviar las particularidades de cada rama del derecho porque la regla de derecho común, producto del desarrollo dogmático, ya la ha incorporado y, por lo tanto, se ha hecho cargo de estas.

Es importante aclarar que vincular la noción actual de derecho común con la dogmática, no implica asumir corrientes doctrinales específicas o algunas que pertenezcan a determinadas disciplinas, ni a una opinión dominante, sea que se base en interpretaciones individuales o colectivas, sin perjuicio de que puedan contar con validez a partir de una disposición vigente en el ordenamiento jurídico. No debe perderse de vista que estas pueden ser múltiples y diferentes entre sí, introduciéndose necesariamente factores subjetivos en el análisis, que afectan la certeza y seguridad jurídica. Tampoco es una referencia a una "teoría dogmática” en particular, como lo sería, por ejemplo, la teoría del negocio jurídico, la teoría del enriquecimiento sin causa. La referencia es, como indicáramos, a los cimientos sobre los que se apoya toda construcción que proporcione o pretenda hacer la doctrina, que han sido originados y desarrollados por esta en el devenir de la institución de que se trata. Dicho de manera simplificada, la remisión al derecho común lo es al acervo común construido por la dogmática jurídica a lo largo del desarrollo histórico del derecho, en el que indiscutidamente apoya sus reflexiones ${ }^{79}$. En términos equivalentes se ha sostenido que, en

Luhmann (1983) p. 34, y Ruiz- Gallardón (2007) pp. 53-60. En esta dirección Larenz, comentando la obra de Luhmann, reconoce que todo orden jurídico está determinado por la existencia expresa o tácita de ciertas “innegabilidades"; la creación de la dogmática se realiza dentro de estos límites. Larenz (2001) p. 222.

78 Con una postura diferente Vergara (2014) pp. 972-974 plantea, a partir de la idea de sistema jurídico, la existencia de autonomía de las distintas disciplinas del derecho, que cuentan con un núcleo dogmático conformado por sus normas, institutos y principios propios que son reflejo de su realidad.

79 Con una opinión distinta, Hernández afirma que la dogmática siempre tiene solo una función descriptiva, sin perjuicio de reconocer que siempre late en ella el deber ser ordenador. Hernández (1981) p. 49-50.

No es objeto de este artículo ahondar ni precisar el carácter de ciencia de la dogmática jurídica, aspecto que ha sido abordado con detalle por la filosofía del derecho. Así, en la doctrina nacional BERNASCONI (2007) p. 33 concluye que el carácter de ciencia de la dogmática jurídica proviene de su verificabilidad. Para una visión general de tema, véase Moresco (1990) pp. 291-313. 
las ciencias, se aceptan acríticamente ciertos presupuestos que determinan la investigación, se trata de dogmas que no son cuestionables ${ }^{80}$. En este sentido, Kuhn alude a la función que cumplen en la investigación científica los "paradigmas", es decir, "logros científicos universalmente aceptados que durante algún tiempo suministran modelos de problemas y soluciones a una comunidad de profesionales" ${ }^{\prime 1}$.

La construcción de este acervo común parte del dato normativo, del derecho positivo. Están inmersos también principios generales del derecho y propios de una determinada materia o área específica, no obstante, no se agota en ellos. La certeza de cuáles son, en concreto, estas reglas de derecho común, conlleva a ahondar en los presupuestos indubitados de la institución de que se trata, que son reiterados desde su creación y durante su desarrollo por la propia doctrina ${ }^{82}$. Así, por ejemplo, el estudio de los contratos bilaterales permite advertir ciertas reglas de derecho común, que han estado presentes históricamente en la evolución de sus efectos particulares y en los que necesariamente se apoya cualquier reflexión jurídica acerca de los mismos: el cumplimiento simultáneo de las obligaciones y el sinalagma funcional.

El derecho común así caracterizado no puede importar la derogación del derecho positivo, pretendiéndose su supuesta primacía. Necesariamente es una construcción que no puede prescindir del dato normativo. No existiría en estos casos un problema de colisión normativa y/o de principios que deba resolverse pudiendo dar preeminencia a alguno de ellos o propugnando su aplicación automática ${ }^{83}$.

La importancia que tiene esta noción de derecho común radica en la función que cumple y ha cumplido dentro del sistema jurídico al permitir la adecuación de la normativa vigente. En efecto, permite adaptarlo a los distintos requerimientos sociales y económicos desde su interior al cumplir una función que va más allá del papel supletorio que tradicionalmente se le ha otorgado a aquello que se significa con la noción derecho común, ya que permite proporcionar soluciones coherentes por la vía de la integración, reduciendo y delimitando cuáles son las alternativas jurídicamente posibles y tolerables al interior del sistema jurídico. Concebido en estos términos permite, por su flexibilidad, proporcionar una solución adecuada al órgano encargado de las operaciones de aplicación del derecho, que se adapte a las condiciones sociales, políticas y económicas imperantes en un momento dado, sin necesidad de acudir a constantes reformas legislativas, velando y tutelando por la coherencia interna del sistema jurídico.

80 Calsamiglia (1982) p. 248, el autor señala expresamente que sigue en este punto a Kuhn.

81 KuHn (2013) p. 94. Desarrolla esta noción, pp. 114 y ss.

82 En cierta medida, se aproxima a nuestra postura la noción amplia de principio general que Mans proporciona: "comprenden todos aquellos conceptos fundamentales y preceptos básicos y elementales que inspiran la conciencia y el sentido jurídicos (principios de derecho y equidad natural, y que informan el sistema de normas que regulan las instituciones (principios sistemáticos del derecho positivo) o la construcción doctrinal o teórica de las mismas (principios de las ciencias del derecho o reglas técnicas jurídica)”. Mans (1979) pp. XXVIIXVIII.

83 No se presentaría una discusión equivalente a la suscitada con los principios generales del derecho tras la influencia, en especial, de Dworkin, quien discurre sobre los conflictos entre los derechos constitucionales, distinguiendo entre principios jurídicos y las reglas. Cfr. DwORKIN (1989) pp. 61-101. 


\section{CONCLUSIONES}

Tras la presente investigación, hemos arribado a las siguientes conclusiones:

1. El legislador nacional, constantemente y en distintos ámbitos, acude a la expresión derecho común como una categoría que está presente en el ordenamiento jurídico. A este derecho común, que puede estar contenido en leyes generales o especiales, le otorga un claro carácter supletorio y, en ciertos casos, un papel de integración, lo que permite asegurar la coherencia interna del sistema jurídico nacional.

2. El contenido de la categoría "derecho común" que el legislador emplea resulta difuso de precisar, de la sola lectura de los cuerpos normativos en que se emplea.

3. Por razones históricas, la primera vinculación posible, para dotar de contenido a la noción de derecho común, es acudir al Código Civil. Sin embargo, el fenómeno de la descodificación, el ámbito propio de vigencia y el contenido de sus disposiciones impiden de manera autónoma considerarlo el ordenamiento jurídico supletorio en las diversas ramas del derecho.

4. En doctrina, este papel también se ha hecho descansar en los principios generales del Derecho. Esta identificación impide solucionar los problemas a que naturalmente está destinada la categoría de derecho común, atendida la dificultad intrínseca de su propia noción, determinación y contenido.

5. Descartamos que el contenido del derecho común se relacione con el texto de la Constitución Política de la República, básicamente, con principios y valores que emanan de la tutela de los derechos fundamentales. Esta asimilación produce un impacto negativo en la propia Constitución, que incide en su fuerza normativa, toda vez que se hace descansar en el intérprete el alcance mismo de la Carta Fundamental, alterándose su tenor. Además, el contenido de estos derechos exige desarrollo por parte de la dogmática jurídica.

6. Tras el análisis efectuado, el elemento comunicador del contenido del derecho común, presente desde sus orígenes históricos, se vincula con la dogmática jurídica.

Este contenido lo proporciona el acervo común construido por la dogmática jurídica, a lo largo del desarrollo histórico de la institución de que se trate, en el que indiscutidamente apoya sus reflexiones. Este determina la extensión y las alternativas de soluciones jurídicas dentro del ordenamiento jurídico, delimitando su posibilidad y, por ende, su debida coherencia. Lo anterior proporciona, además, flexibilidad al propio sistema, en orden a adaptarse a los distintos requerimientos sociales sin necesidad de una constante reforma legislativa.

\section{BIBLIOGRAFÍA CITADA}

ARCE, Joaquín (1990): Los principios generales del derecho y su formulación constitucional (Madrid, Cuadernos Civitas).

Aarnio, Aulis (1985): "Sobre el paradigma de la dogmática jurídica", Revista de la Facultad de Derecho, Universidad del Zulia, No 64: pp. 175-192.

Aguiló, Josep (2000): Teoría General de las fuentes del Derecho (y el orden jurídico) (Barcelona, Ariel) 
AlCalde, Enrique (2003): Los principios generales del Derecho (Santiago, Ediciones Universidad Católica de Chile).

AlCAlde, Enrique (2008): "La relación entre valores y principios generales del derecho en la interpretación constitucional de los derechos fundamentales en Chile", Revista Chilena de Derecho, vol. XXXV, No 3: pp. 463-483.

AldunAte, Eduardo (2001): "La desconstitucionalización de la Constitución", Revista de Derecho de la Pontificia Universidad Católica de Valparaíso, vol. XII: pp. 17-36.

Aldunate, Eduardo (2009): "La fuerza normativa de la Constitución y el sistema de fuentes del Derecho", Revista de Derecho de la Pontificia Universidad Católica de Valparaiso, vol. XXXII: pp. 443-484.

Barros, Enrique (2006): Tratado de responsabilidad extracontractual (Santiago, Editorial Jurídica de Chile).

Bernasconi, Andrés (2007): "El carácter científico de la ciencia jurídica”, Revista de Derecho de la Universidad Austral de Chile, vol. XX, No 1: pp. 9-37.

BERMúdEZ, Jorge (2012): Las relaciones entre el derecho administrativo y el derecho común (Santiago, LegalPublishing).

Brantt, María Graciela y Mejías, Claudia (2016): “El derecho supletorio del contrato de servicios en el código civil chileno. Insuficiencia de las reglas del mandato y del arrendamiento", Revista de Derecho de la Pontificia Universidad Católica de Valparaíso, vol. XLVI: pp. 71-103.

Bordalí, Andrés (2007): "La unidad en la interpretación jurisdiccional de los derechos fundamentales: una tarea pendiente en el derecho chileno", Revista Chilena de Derecho, vol. XXXIV, No 3: pp. 517-538.

Bulnes, Luz (1998): "Fuerza Normativa de la Constitución", Revista Chilena de Derecho, No especial: pp. 137-142.

Calasso, Francesco (1954): Medioevo del Diritto (Milano, Giuffrè).

Calsamiglia, Albert (1982): "Sobre la dogmática jurídica: presupuestos y funciones del saber jurídico", Anales de la cátedra de Francisco Suárez, vol. XXII: pp. 235-276.

CANARIs, Claus-Wilhelm (1998): El sistema en la jurisprudencia (trad. Juan Antonio García Amado, Madrid, Fundación Cultural del Notariado).

Catalano, Pierangelo (2006): "Sistema y ordenamientos: el ejemplo de América Latina", en FabIO, David (edit.), Sistema Jurídico Latinoamericano y Unificación del Derecho (México, Editorial Porrúa) pp. 51-74.

Corng, Helmut (1981): "Historia del Derecho y dogmática jurídica”, Revista de Estudios Histórico-Jurídicos, vol. VI: pp. 105-118.

Cordero, Eduardo (2009): "Los principios y reglas que estructuran el ordenamiento jurídico chileno", Ius et Praxis, vol. XV, No 2: pp. 11-49.

CORRAL, Hernán (2004): "Algunas reflexiones sobre la constitucionalización del derecho privado", Derecho Mayor, No 3: pp. 47-63.

CORRAL, Hernán (2013): Lecciones de responsabilidad civil extracontractual (Santiago, Editorial Jurídica).

Corral, Hernán (2016): "Sobre la Ley No 20.830, que crea el Acuerdo de Unión Civil: Una primera (y crítica) Mirada”, Revista de Derecho de Familia, vol. I, No 9: pp. 33-44. 
Corzo, Edgar (2014): "Derecho común y espacio común latinoamericano". Disponible en: http://www.edgarcorzo.com/wp-content/uploads/2014/03/DerechoComun.pdf. Fecha de consulta: 21 de marzo de 2016.

Cossio, Carlos (1939): La plenitud del orden jurídico y la interpretación judicial de la ley (Buenos Aires, Editorial Losada).

CourT, Eduardo (2016): "Legitimación activa del conviviente civil para reclamar indemnizaciones derivadas de los perjuicios a que hubiere lugar por el hecho ilícito de un tercero que hubiere causado el fallecimiento de su conviviente civil o lo imposibilite para ejercer por sí mismo las acciones legales", Revista de Derecho de Familia, vol. I, No 9: pp. 57-68.

Cuena, Francisco (1998): Sistema jurídico y derecho romano (Santander, Universidad de Cantabria).

DARÍO, Norberto (2014): Quinta Jornada sobre orígenes romanisticos de los principios generales del derecho (Buenos Aires, Universidad de Flores).

De los Mozos, José Luis (2006a): "Perspectivas y método para la comparación jurídica en relación con el derecho privado iberoamericano", en FABIO, David (edit.), Sistema Jurídico Latinoamericano y Unificación del Derecho (México, Editorial Porrúa) pp. 159-173.

De los Mozos, José Luis (2006b): “Tradición jurídica y principios generales”, en Fabio, David (edit.), Sistema Jurídico Latinoamericano y Unificación del Derecho (México, Editorial Porrúa) pp. 195-208.

Del Vecchio, Giorgio (1971): Los principios generales del derecho (trad. Juan Ossorio, Barcelona, Bosch).

Domínguez, Ramón (1996): "Aspectos de la constitucionalización del Derecho Civil chileno", Revista de Derecho y Jurisprudencia, T. XCIII: pp. 107-137.

Domínguez, Carmen (2009): "Los derechos de la personalidad y el principio de reparación integral del daño”, en Pizarro, Carlos (edit.), Estudios de Derecho Civil VI (Santiago, LegalPublishing) pp. 645-659.

Donato, Francesco (2005): "Métodos de codificación: Código Civil y leyes sectoriales", en Martinic et al. (edit.), Sesquicentenario del Código Civil de Andrés Bello (Santiago, Editorial LexisNexis) pp. 957-966.

Dworkin, Ronald (1989): Los derechos en serio (trad. Marta Gustavino, Barcelona, Ariel).

EsSER, Josef (1961): Principio y norma en la elaboración jurisprudencial del derecho privado (trad. Eduardo Valentí, Barcelona, Bosch).

Favoreu, Louis (2001): "La Constitucionalización del derecho", Revista de Derecho de la Universidad Austral, vol. XII: pp. 31-43.

FERnÁNDEZ-CARVAJAL, Rodrigo (1989): "Nota sobre el derecho constitucional como nuevo "derecho común", en Universidad de Murcia (edit.), Homenaje al profesor Juan Roca Juan (Murcia, Universidad de Murcia) pp. 257-264.

Fernández, Miguel (2001): "La fuerza normativa de la Constitución”, Revista de Derecho Público, No 63: pp. 77-102.

GarCÍA DE EnTERría, Eduardo (1984): Reflexiones sobre la ley y los principios generales del Derecho (Madrid, Civitas). 
García, Guillermo (1975): "Los principios generales del Derecho en el nuevo Título Preliminar del Código Civil”, Anuario de Derecho Civil, vol. XXVII, No 2: pp. 331-336.

Gordillo, Antonio (1988): "Ley, Principios Generales y Constitución: Apuntes para una relectura, desde la Constitución, desde la Teoría de las Fuentes del Ordenamiento Jurídico", Anuario de Derecho Civil, vol. XLI, No 2: pp. 469-516.

Grossi, Paolo (1996): El orden Jurídico Medieval (trad. Francisco Tomás y Valiente, Madrid, Marcial Pons).

Guzmán, Alejandro (1989-1990): "El concepto de Ius Commune en el lenguaje de los juristas romanos", Revista de Derecho Universidad Católica de Valparaíso, vol. XIII: pp. 3978.

Guzmán, Alejandro (1999): "Acerca de las fuentes del Derecho. A. Proposición del profesor Alejandro Guzmán y sus colaboradores”, en Fundación Fernando Fueyo (edit.), Estudios sobre reformas al Código Civil y Código de Comercio (Santiago, Editorial Jurídica de Chile) pp. 31-69.

GuZMán, Alejandro (2006): "La función del derecho romano en la unificación jurídica de Latinoamérica”, en FABIO, David (edit.), Sistema Jurídico Latinoamericano y Unificación del Derecho (México, Editorial Porrúa) pp. 177-185.

Guzmán, Alejandro (2011): Codificación del Derecho Civil e interpretación de las leyes (Madrid, Editorial Iustel).

GuZMÁn, Alejandro (2014a): “La idea de 'principio' mentada en la expresión "principios generales del derecho", en Reinoso, Fernando (edit.), Principios generales del derecho. Antecedentes históricos y horizonte actual (Madrid, Aranzandi) pp. 1-9.

GuZMÁn, Alejandro (2014b): El origen y la expansión de la idea de principio del derecho (Santiago, Thomson Reuters).

GuZmán, Nicolás (2016): Análisis crítico desde la perspectiva del derecho común de las normas de prescripción de las acciones indemnizatorias comprendidas en el artículo 69 letra b) de la ley No 16.744. [Seminario de Titulación Magíster en Derecho, mención Derecho Privado, Pontificia Universidad Católica de Valparaíso].

Hernández, Antonio (1981): La ciencia jurídica y su transformación (Madrid, Civitas).

IRTI, Natalino (1979): L'etá della decodificazione (Roma, Giuffrè).

Kunn, Thomas (2013): La estructura de las revoluciones cientificas (trad. Agustín Cotin, México, Fondo de la Cultura Económica, cuarta edición).

Larenz, Karl (2001): Metodología de la ciencia del derecho (trad. Marcelino Rodríguez, Barcelona, Editorial Ariel, segunda edición).

Losano, Mario (2002): Sistema e structura nel diritto, Tomo I, II y III (Milano, Guiffrè Editore).

Luhmann, Niklas (1983): Sistema Jurídico y Dogmática Jurídica (trad. Ignacio de Otto, Madrid, Centro de Estudios Constitucionales).

MANS, Jaime (1979): Los principios generales del derecho: repertorio de reglas, máximas y aforismos juridicos con la jurisprudencia del Tribunal Supremo de Justicia (Barcelona, Bosch).

Martínez, Juan Antonio (1993): "Principios del Derecho y normas jurídicas", en Vallet, Juan (edit.), Los Principios Generales del Derecho (Madrid, Editorial Actas) pp. 89-108. 
Martínez-Sicluna, Consuelo (1993): "Concepto y contenido de los principios generales del Derecho”, en Vallet, Juan (edit.), Los Principios Generales del Derecho (Madrid, Editorial Actas) pp. 25-58.

Moresco, José (1990): “Ciencia jurídica y dualismo metodológico", Anuario de Filosofía del Derecho, vol. VII: pp. 291-313.

Núñez, María Isabel (2000): Derecho Romano, Derecho común y contratación en el marco de la Unión Europea (Guijón, Universidad de Oviedo).

Pérez, Antonio (1999): “El Ius Commune: artificio de juristas”, en De Montagut, Tomás (edit.), História del pensament jurídic (Barcelona, Colección Ágora) pp. 69-91.

Pinedo, Montserrat (2016): Análisis crítico de sentencias que se pronuncian sobre el daño extrapatrimonial en personas jurídicas a la luz del derecho común [Seminario de Titulación Magíster en Derecho, mención Derecho Privado, Pontificia Universidad Católica de Valparaíso].

Pizarro, Carlos (1998): "Los derechos fundamentales y los contratos. Una mirada a la drittwirkung", Gaceta Jurídica, No 221: pp. 7-21.

Rodríguez Pinto, María Sara (2014): "Responsabilidad por incumplimiento de contratos de servicios", Revista Chilena de Derecho, vol. XLII, No 3: pp. 791-893.

Ruiz-Gallardón, Isabel (2007): La mente del jurista (Pamplona, Editorial Aranzandi, primera edición).

SÁnchez de la Torre, Ángel (1993): "Los principios del Derecho como objeto de investigación jurídica, en Vallet, Juan (edit.), Los Principios Generales del Derecho (Madrid, Editorial Actas) pp. 13-24.

SÈve, René (1986): "Système et Code", Archives de Philosophie du droit, No 31: pp. 77-84.

SQuella, Agustín (2011): Introducción al Derecho (Santiago, Editorial Jurídica de Chile, segunda edición).

TAPIA, Mauricio (2005): “Codificación: entre pasión y desencanto por las leyes", en MARTINIC et al. (edit.), Sesquicentenario del Código Civil del Andrés Bello (Santiago, Editorial LexisNexis) pp. 967-985.

TAPIA, Mauricio (2007): "Constitucionalización del derecho de familia(s) el caso chileno: Las retóricas declaraciones constitucionales frente a la lenta evolución social”, Revista Chilena de Derecho Privado, No 8: pp. 155-202.

TARDío, José Antonio (2011): Los principios generales del derecho (Barcelona, Editorial Bosch).

Vergara, Óscar (2009): "Sistemas jurídicos y sistemas normativos en el pensamiento de C.E. Alchourrón y E. Bulygin”, en Vergara, Oscar (edit.), Teorías del Sistema Jurídico (Granada, Editorial Comares) pp. 225-305.

Vergara, Alejandro (2010): El derecho administrativo como sistema autónomo (Santiago, Abeledo Perrot).

Vergara, Alejandro (2014): "Sistema y autonomía de las disciplinas jurídicas. Teoría y técnica de los núcleos dogmáticos”, Revista Chilena de Derecho, vol. XLI, No 3: pp. $957-$ 991.

Vodanovic, Antonio (2005): Tratado de derecho civil partes preliminar y general, Explicaciones basadas en las versiones de clases de los profesores de la Universidad de Chile Arturo 
Alessandri R. y Manuel Somarriva U., Tomo I (Santiago, Editorial Jurídica, séptima edición).

Von Bogdandy, Armin (2014): "Ius Constitucionale Commune Latinoamericanum. Una aclaración conceptual”. Disponible en https://biblio.juridicas.unam.mx/bjv/detallelibro/3655-ius-constitutionale-commune-en-america-latina-rasgos-potencialidades-ydesafios. Fecha de consulta: 20 de junio de 2016.

WIEACKER, Franz (1998): Fundamentos de la formación del sistema en la jurisprudencia romana (trad. José Luis Carro, Granada, Comares).

\section{NORMAS CITADAS}

Constitución Política de la República.

Código Civil.

Código de Comercio.

Código Orgánico de Tribunales.

Código de Procedimiento Civil.

Código Tributario.

Código Aeronáutico.

Código de Minería.

LEY No 16.744 (1/2/1968), Establece normas sobre accidentes del trabajo y enfermedades profesionales.

DFL 5 (1968), Texto que modifica, complementa y refunde la normativa sobre Comunidades Agrícolas.

LEY No 18.097 (21/1/1982), Ley orgánica constitucional sobre concesiones mineras.

LEY No 18.168 (15/9/1982), Ley General de Telecomunicaciones.

Ley No 18.290 (7/2/1984), Ley de Tránsito.

LEY No 18.302 (2/5/1984), Seguridad Nuclear.

LEY No 18.490 (4/1/1986), Establece el seguro obligatorio de accidentes personales causados por la circulación de vehículos motorizados.

LEY No 18.712 (4/6/1988), Aprueba nuevo estatuto de bienestar social de las FF.AA.

LEY No 18.713 (4/6/1988), Aprueba nuevo estatuto de la Dirección de bienestar de Carabineros de Chile.

LEY No 18.714 (4/6/1988), Aprueba nuevo estatuto de la Jefatura de bienestar social de la PDI.

LEY No 18.605 (6/4/1987), Ley orgánica constitucional de los Consejos Regionales de Desarrollo.

LEY No 18.845 (3/11/1989), Establece sistema de microcopia o micrograbación de documentos.

LEY No 19.253 (5/10/1993), Sobre protección, fomento y desarrollo de los indígenas.

DFL No 3 (19/12/1997), Texto refundido y sistematizado de la Ley General de Bancos

LEY No 19.537 (16/12/1997), Sobre copropiedad inmobiliaria.

LEY No 19.857 (11/2/2003), Autoriza el establecimiento de empresas individuales de responsabilidad limitada. 
LeY No 19.886 (30/07/2003), Ley de bases sobre contratos administrativos de suministro y prestación de servicios.

DFL 1 que fija el texto de la Ley No 18.695 (26/7/2006), Ley orgánica constitucional de Municipalidades.

LEY No 20.385 (24/10/2009), Norma que faculta al Fisco para comprar y vender propiedades particulares con ocasión de la erupción del volcán Chaitén.

LEY No 20.392 (14/11/2009), Modifica el estatuto orgánico de Codelco.

LEY No 20.500 (16/2/2011), Sobre Asociaciones y participación ciudadana en la gestión pública.

LEY No 20.550 (26/10/2011), Modifica la ley 20.248 de subvención escolar preferencial.

LEY No 20.830 (21/4/2015), Acuerdo de Unión civil.

\section{JURISPRUDENCIA CITADA}

Zorín CON Compañía (2012): Corte Suprema, 31 de octubre de 2012, en Vlex, Código de búsqueda 436177870, fecha de consulta 15 de junio de 2016.

SOCIEDAD CON BANCO SANTANDER (2015): Corte de Apelaciones de Antofagasta, 12 de enero de 2015, en Thomson Reuters, Código de búsqueda CL/JUR/113/2015, fecha de consulta 26 de octubre de 2017.

SOCIEDAD CON ARRIAGADA (2011): Corte de Apelaciones de Talca, 18 de octubre de 2011, en Thomson Reuters, Código de búsqueda CL/JUR/8271/2011, fecha de consulta 26 de octubre de 2017.

SOCIEDAD CON YOSHIO (2010): Corte de Apelaciones de Santiago, 2 de septiembre de 2010, en Thomson Reuters, Código de búsqueda CL/JUR/6570/2010, fecha de consulta 26 de octubre de 2017.

CLÍNICA CON MEZA (2009): Corte de Apelaciones de Santiago, 23 de noviembre de 2009, en Thomson Reuters, Código de búsqueda CL/JUR/3841/2009, fecha de consulta 26 de octubre de 2017.

INDUSTRIA CON BBVA (2008): Corte de Apelaciones de Concepción, 29 de septiembre de 2008, en Thomson Reuters, Código de búsqueda CL/JUR/5701/2008, fecha de consulta 26 de octubre de 2017.

\section{SENTENCIAS DEL TRIBUNAL CONSTITUCIONAL CITADAS}

CONTROl DE CONSTITUCIONALIDAD RESPECTO DEL PROYECTO DE LEY QUE MODIFICA LAS LEYES ORGÁNICO CONSTITUCIONALES Nos 18.556 y 18.583 (1987): Tribunal Constitucional chileno, Rol No 46, 22 de junio 1987.

Requerimiento de un grupo de Diputados acerca del proyecto de ley Que rebaja la TASA DE LOS ARANCELES A LAS IMPORTACIONES E INTRODUCE MODIFICACIONES A OTRAS NORMAS TRIBUTARIAS Y ECONÓMICAS (1998): Tribunal Constitucional chileno, Rol No 280, 16 de septiembre de 1998.

Requerimiento por inconstitucionalidad presentado por el señor Carlos OMinami Pascual respecto de los artículos 2.331 del Código Civil y 40, inciso segundo, de 
LA LEY No 19.733, SOBRE LIBERTADES DE OPINIÓN E INFORMACIÓN Y EJERCICIO DEL PERIOdismo, en la causa Rol IC 800-08, Caratulada Ominami con Urbano y otros (2008): Tribunal Constitucional chileno, Rol No 1185, 28 de julio de 2008.

REQUERIMIENTO DE INAPLICABILIDAD POR INCONSTITUCIONALIDAD PRESENTADO POR EL SEÑOR José Miguel Fernández García Huidobro respecto del artículo 2331 del Código Civil, EN LA CAUSA Rol No 1324-2011, SEgUIDA EN JUICIO ORDINARIO DE INDEMNIZACIÓN de perjuicios caratulada Fernández con Pinto (2013): Tribunal Constitucional chileno, Rol No 2410, 24 de enero de 2013.

REQUERIMIENTO DE INAPLICABILIDAD POR INCONSTITUCIONALIDAD PRESENTADO POR EL SEÑOR Eduardo Elberg Simi respecto del artículo 2331 del Código Civil, en la causa Rol 23.844-2012, SEGUIDA EN JUICIO ORDINARIO DE INDEMNIZACIÓN DE PERJUICIOS CAratulada "Elberg con Bacigaluppi” (2014): Tribunal Constitucional chileno, Rol No 2747, 26 de noviembre de 2014.

REQUERIMIENTO DE INAPLICABILIDAD POR INCONSTITUCIONALIDAD PRESENTADO POR EL SEÑOR Hernán Tuane Valenzuela respecto del artículo 2331 del Código Civil, en la CauSA Rol 6307-2014, SEgUida EN JUICIO ORdiNARIO SOBRE INDEMNIZACIÓN DE PERJUICIOS caratulada "Tuane Valenzuela, Hernán con Meersohn Ferrer, Marcia Eugenia y OTRAS” (2015): Tribunal Constitucional chileno, Rol No 2801, 26 de febrero de 2015.

REQUERIMIENTO DE INAPLICABILIDAD POR INCONSTITUCIONALIDAD PRESENTADO POR EL SEÑOR Claudio Valls Morales y otros respecto del artículo 2331 del Código Civil, en la

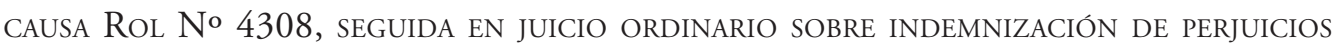
Caratulada "Valls con Red de Televisión Chilevisión S.A.” (2015): Tribunal Constitucional chileno, Rol No 2860, 6 de julio de 2015.

REQUERIMIENTO DE INAPLICABILIDAD POR INCONSTITUCIONALIDAD PRESENTADO POR EL SEÑOR Jorge Yarur Bascuñán respecto del artículo 2.331 del Código Civil, en la causa Rol No 20.668-2014, SEGUIDA EN JUICIO ORDINARIO SOBRE INDEMNIZACIÓN DE PERJUICIOS Caratulada "Yarur con Hatala" (2015): Tribunal Constitucional chileno, Rol No 2887, 20 de agosto de 2015. 